\title{
Frontline managers' contribution to mission achievement: A study of how people management affects thoughtful care
}

\section{Eva Knies, Peter Leisink \& Sascha Kraus-Hoogeveen}

To cite this article: Eva Knies, Peter Leisink \& Sascha Kraus-Hoogeveen (2018) Frontline managers' contribution to mission achievement: A study of how people management affects thoughtful care, Human Service Organizations: Management, Leadership \& Governance, 42:2, 166-184, DOI: $10.1080 / 23303131.2017 .1422067$

To link to this article: https://doi.org/10.1080/23303131.2017.1422067

$$
\begin{aligned}
& \text { (c) } 2018 \text { The Author(s). Published by Taylor \& } \\
& \text { Francis. }
\end{aligned}
$$

Accepted author version posted online: 02
Jan 2018.
Published online: 09 Jan 2018.
Submit your article to this journal

\section{Џll Article views: 1017}

View Crossmark data $\nearrow$ 


\title{
Frontline managers' contribution to mission achievement: A study of how people management affects thoughtful care
}

\author{
Eva Knies $^{a}$, Peter Leisink ${ }^{a}$, and Sascha Kraus-Hoogeveen ${ }^{b}$ \\ aUtrecht University School of Governance, Utrecht University, Utrecht, The Netherlands; 'bnstitute for Management \\ Research, Radboud University Nijmegen, Nijmegen, The Netherlands
}

\begin{abstract}
This study addresses the question to what extent frontline managers' people management activities contribute to mission achievement through frontline workers' behaviors. Drawing on the case of elderly care, we contribute to the literature by: (1) providing a compact measure of mission achievement in elderly care and specifying the requisite employee behaviors; and (2) showing that frontline managers' people management activities impact on employees' behaviors, and ultimately on mission achievement. In doing so, we also contribute to more knowledge about elderly care, which is an under-researched sector, and about the role of line managers (instead of top managers) in HRM implementation.
\end{abstract}

\section{ARTICLE HISTORY}

Received 3 September 2016

Revised 21 May 2017

Accepted 23 May 2017

\section{KEYWORDS}

Frontline managers; mission achievement; HRM;

employee behaviors; elderly care

\section{Introduction}

Performance continues to be one of the most studied topics in management research, both of business organizations (Richard, Devinney, Yip, \& Johnson, 2009) and of nonprofit and public organizations (Andersen, Boesen, \& Pedersen, 2016; Andrews, Boyne, \& Walker, 2006). Business management research is predominantly interested in organizational performance with a focus on financial, market, and shareholder performance indicators (Richard et al., 2009, p. 722). Researchers of nonprofit and public organizations prefer the term organizational effectiveness (Sowa, Selden, \& Sandfort, 2004) or use the terms organizational effectiveness and performance interchangeably (Rainey \& Steinbauer, 1999) as they recognize that these organizations have different types of goals, which are often multiple.

Studies of nonprofit and public organizations use a multitude of performance indicators. This is illustrated by Andrews and Boyne's (2010) study of English local governments, which assesses organizational performance on the basis of 108 best value performance indicators. Although Andrews, Boyne and Walker (2006, p. 15) claim that 'clarity has been brought to the criteria of performance' by Boyne's (2002) proposal to distinguish between five conceptual categories, it is still hard to see the forest from the trees represented by tens and hundreds of performance indicators suggested by performance studies. Here, we argue that to address these measurement issues we need a compact singular measure of effectiveness that can be used across public and nonprofit human service organizations. One such compact measure would be a tailored measure of mission achievement: the extent to which an organization achieves its ultimate goals. The focus on mission achievement follows from Rainey and Steinbauer (1999) who define organizational effectiveness as follows: 'the agency performs well in discharging the administrative and operational functions pursuant to the mission' (p.13). We follow their view that 'evidence that the agencies' operations have contributed substantially to the achievement of these goals [included in the mission] provides evidence of agency effectiveness' (p. 13). The need for a measure of mission achievement is also felt 
in practice as human service organizations find it hard to define client outcomes that adequately capture the nature of the human service they provide (Carnochan, Samples, Myers, \& Austin, 2014).

Studies of organizational performance or effectiveness as a rule are interested in the question how performance/effectiveness can be achieved (Lynn, Heinrich, \& Hill, 2000). Typically, these studies focus on management's contribution to performance. More specifically, conceptual models (e.g. Rainey \& Steinbauer, 1999; Sowa et al., 2004) as well as empirical studies (e.g. Andrews \& Boyne, 2010; Meier, O'Toole, Boyne, \& Walker, 2007; Moynihan \& Pandey, 2005) tend to concentrate on the contribution of top managers, maybe as a result of their interest in the effect of management systems and strategies. In doing so, these studies tend to ignore the role of frontline managers, who are typically responsible for supervising frontline employees and can be expected to contribute to performance because they are close to the service delivery process (Guest, 2011). Since frontline employees are critical agents in the provision of human services, how these employees are managed is of great relevance (Wright \& Nishii, 2013). Therefore, in this study we will focus on frontline managers' people management activities aimed at supporting the employees they supervise at work. Following the human resource management (HRM) literature and the work of Purcell and Hutchinson (2007) in particular, people management refers to line managers' implementation of HRM practices and their leadership behavior. In doing so, we add to the knowledge base on how management affects performance outcomes by looking at a particular set of management activities (i.e. people management by frontline managers), and by making clear decisions about how outcomes are specified (i.e. mission achievement). The question of frontline managers' contribution to performance or effectiveness is particularly relevant in the context of nonprofit or public human service organizations. It is often suggested that frontline managers in nonprofit or public organizations may have limited impact on performance because of constraints imposed by government directives, red tape, and detailed regulations which apply particularly to the area of personnel management (Brewer \& Walker, 2012; Feeney \& Rainey, 2010). This raises the question to what extent people management activities of frontline managers in nonprofit and public human service organizations are related to mission achievement through employees' behaviors (see also Riccucci, 2005).

Therefore, the research question which this article answers is: to what extent do frontline managers' people management activities contribute to mission achievement through front-line workers behaviors? Drawing on the case of elderly care, this article's contribution to the literature on performance and human service management is twofold. First, we contribute by providing a compact (i.e. a short and reliable) measure of mission achievement in elderly care and specifying the requisite employee behaviors, which represent respectively the product and process dimensions of service provision (Donabedian, 1980). Second, this article contributes by showing to what extent frontline managers' people management activities impact on employees' behaviors, and ultimately on mission achievement in elderly care. In doing so, we also contribute to more knowledge about elderly care, which is an under-researched sector, and about the role of line managers in implementation linked to quality of care, as called for by Cooke and Bartram (2015) in their introduction to a recent special issue of Human Resource Management, entitled 'Human Resource Management in health care and elderly care: current challenges and toward a research agenda'.

\section{Theoretical framework}

In this section, we substantiate the argument that frontline managers' people management activities are positively related to mission achievement through frontline workers' behaviors by combining insights from the public management and HRM bodies of literature.

\section{Mission achievement}

Nonprofit and public organizations researchers agree that performance is multidimensional and that the primary thing that researchers have to define is the stakeholders whose interests are taken into account when measuring performance (Andersen et al., 2016; Richard et al., 2009). Different 
stakeholders hold different views on good performance and different performance dimensions are of varying interest to them. This can be illustrated by the dimensions of public service performance of local authorities which are distinguished by Boyne (2002): outputs, efficiency, service outcomes, responsiveness, and democratic outcomes. For instance, responsiveness can be seen from the perspective of the direct service user, whose preferences as a recipient of social services are matched, or from the perspective of the wider community of local citizens who are interested as taxpayers. Efficiency also relates to taxpayers' interests while it is of less interest to the direct service user. Therefore, it is necessary to be explicit about the focal stakeholder(s) whose interests are the basis for constructing a measure of mission achievement.

According to Hasenfeld (2015, p. 1), the common mission of human service organizations is 'to meet the social welfare needs of vulnerable populations, reduce social inequality and advocate social rights'. From the perspective of society as a whole this description relates to the service and democratic outcomes dimensions in Boyne's concept of performance. From the perspective of individual service users this mission description relates to outputs (the quantity and quality of service), service outcomes (longer term effects), and responsiveness (user satisfaction). For the purpose of this article, we follow the view that a service user-based conception of quality can be regarded as closely aligned with the goals of human service organizations and that user outcomes are the bottom line (Cronley \& Kim, 2014, p. 75, 86). This means that for a compact measure of mission achievement it is important to take into account three public service performance dimensions distinguished by Boyne (2002): outputs, service outcomes, and responsiveness, as these concern the primary service quality interests of the service user.

In terms of operationalizing mission achievement, we observe that studies of organizational performance have resulted in a multitude of performance indicators but do not provide a compact measure of mission achievement (e.g. Andrews \& Boyne, 2010). Thus, it might seem attractive to fill this gap by constructing one or two questions asking service users to rate the service quality experienced directly. However, earlier discussions of measurement validity regarding organizational performance provide important warnings to take into account. Meier and O'Toole (2013) note that the bias in perceptual assessments is greater the more general a performance indicator is. They argue that the correlation between subjective assessment and objective performance information is greater in the case of more specific indicators (see also Richard et al., 2009, p. 735).

There is also a theoretical reason for concern about using general questions to gauge mission achievement. General questions do not tap into the mission of specific organizations, because they neglect that such a measure means something different in the case of elderly care than in the case of for instance secondary education. Making a similar observation about the difference between mental health programs and early childhood or welfare-to-work programs, Sowa et al. (2004, p. 717) argue that measures of what they call 'program effectiveness', which refers to the effectiveness of the specific service or interventions offered by nonprofit organizations, will generally vary depending on the nature of the programs operated. Measures should capture the degree to which the program achieves its purposes and should tap into the 'service technology underlying the program process in order to demonstrate whether these processes are effective' (Sowa et al., 2004, p. 720).

Applying these insights to the case of elderly care in the Netherlands and the mission to provide 'thoughtful care', our purpose is to create a compact measure gauging this mission in terms of questions tapping specific aspects of thoughtful care which reflect the interests of the client as the focal stakeholder. Thoughtful care is conceptualized as care aimed at supporting the autonomy, relatedness, and healthy life of elderly clients (for an elaborate discussion see Research Context). This interest in thoughtful care is not restricted to elderly care in the Netherlands. In their introduction to a special issue on the development of long-term care for older people in Europe, Deusdad, Pace, and Anttonen (2016) also address this topic. They observe a strategy pursued by governments to cope with the costs of welfare policies and the challenge of aging societies, which leads to deinstitutionalization and privatization of long-term care. Deusdad et al. also note a reappraisal of family care and 
traditional care values. Indeed, since the 2008 economic and state financial crisis the Dutch government has stepped up its policies to deinstitutionalize long-term care for older people and make them live at home as long as possible with the help of their social networks. However, older people with complex health problems who can no longer live at home will continue to depend on the medical and non-medical care provided by residential homes. The challenge for these organizations is to provide thoughtful care akin to the quality associated with family care.

\section{Frontline managers' people management}

Given that frontline employees are critical agents in the provision of human services, how these employees are managed is of great relevance. Therefore, we now turn to frontline managers' contribution to mission achievement, in particular their people management activities. The question how to achieve performance has been a core issue in HRM research (Guest, 2011; Paauwe, 2009) ever since Huselid's (1995) study which showed that HRM has a positive effect on organizational performance. There is an increasing interest in high performance work systems (HPWSs), representing the whole system or subsystems of HR practices, which are designed to enhance performance and improve employee outcomes. This interest has also led to studies of HPWSs in human services organizations (Boselie \& Veld, 2012; Selden \& Sowa, 2015). HR practices that are often included in studies of HPWSs are: training and development, participation and autonomy, performance appraisal and rewards, teamwork, work-life balance, recruitment and selection, and employment security (Boon, Den Hartog, Boselie, \& Paauwe, 2011).

Unfortunately, these studies' interest in HR systems has not been complemented by an interest in their implementation by frontline managers. However, a study by Ang, Bartram, McNeil, Leggat, and Stanton (2013) shows that the intended effects of HPWSs is dependent on whether management's implementation of HPWSs is similar to the espoused policy. This finding supports current HRMperformance models (Purcell \& Kinnie, 2007; Wright \& Nishii, 2013) which distinguish between intended HR policy, implemented HR practices, and employees' perceptions of the HR implementation, which have an impact on employees' attitudes and behaviors, and hence on performance outcomes. The literature draws attention to several HR 'delivery channels', such as HR professionals, HR service centers, and line managers. In this article, we specifically focus on frontline managers as organizational agents because in many organizations frontline managers have an important responsibility for HRM (Brewster, Brookes, \& Gollan, 2015).

According to Purcell and Hutchinson (2007), employees' perceptions are not only influenced by their line managers' HR implementation, but also by their leadership behavior. They state that: 'the twin aspects of FLMs' [frontline managers] people management activities, leadership behaviour and the application of HR practices, imply a symbiotic relationship between them. FLMs need well designed HR practices to use in their people management activities [...] The way FLMs enact these practices will be influenced by their leadership behaviour' (pp. 3-4). They coined the term people management to cover both aspects. Following Purcell and Hutchinson, people management is defined as line managers' implementation of HR practices and their leadership behavior in supporting the employees they supervise at work.

The first element of the people management concept, the implementation of HR policies, has its roots in the HR devolution literature. According to Larsen and Brewster (2003, p. 228), 'the notion of line management accepting greater responsibility for human resource management within employing organizations is now received wisdom'. When studying the impact of HRM on employees it is important to focus not only on the presence of specific HR practices but also on perceptions that employees have of the reasons why management adopts certain HR practices (so-called HR attributions). Nishii, Lepak, and Schneider (2008) show that practices that are perceived as commitmentfocused (i.e. intended to enhance service quality and employee wellbeing) are positively related to employee attitudes, while practices that are perceived as control-focused (i.e. designed to reduce costs and exploit employees) are negatively associated with their attitudes. Therefore, when studying 
the implementation of HR practices by line managers it is important to determine to which extent employees feel supported or controlled by the implementation of these practices. Following Guest (2007), we distinguish two levels of HR implementation. On the one hand, line managers implement general practices, ones that apply to all employees in their team. On the other hand, line managers are increasingly expected to make tailor-made arrangements with individual employees. HR practices established at the organizational level outline the framework for such deals.

The relevance of the second element of the people management concept, leadership behavior, builds on theories of social exchange and perceived organizational support (POS). Based on social exchange theory, Eisenberger, Huntington, Hutchinson, and Sowa (1986) argue that employees who experience high levels of POS feel that they ought to reciprocate and engage in behaviors that support organizational goals. Organizational support theory holds that employees see supervisors as agents acting on behalf of the organization, and therefore regard the degree to which supervisors value their contributions and care about their wellbeing as an important indicator of the organization's support (Rhoades \& Eisenberger, 2002). In this article, leadership behavior is understood as a manager demonstrating supportive behavior through specific acts that have the intention of helping one's employees. More specifically Greenhaus, Parasuraman, and Wormley (1990) describe supportive behavior by supervisors as including the provision of career guidance, performance feedback, and opportunities that promote employee development. Oldham and Cummings (1996) observe that supervisors are supportive when they show concern for their employees' feelings and needs, encourage them to voice their own concerns, provide feedback, and facilitate their development.

\section{Employees' behavior: linking people management and mission achievement}

Although managers are assumed to play an important role in managing performance, their contribution is indirect. Frontline employees play a pivotal role in service provision and it is through managing their employees' behavior that managers have an impact on performance. This is the assumption underlying HRM-performance models (Purcell \& Kinnie, 2007; Wright \& Nishii, 2013) which hypothesize that employees' perceptions of their line managers' people management impact on performance through employees' behaviors. This assumption is based on the resource-based view (RBV) of the firm, which holds that the viability and performance of an organization result from the effective interaction of scarce, inimitable, and non-substitutable human and non-human resources (Barney, 1991). One of the underlying assumptions of the $\mathrm{RBV}$ is that human resources can be managed in order to increase the value of their contribution.

The importance attributed to employees' behaviors resonates with Donabedian's (1980) framework for organizing quality of care. This involves that the behaviors of nursing staff in giving care are the link between the system that provides care, which includes such organizational characteristics as review practices and continuing education programs for nursing staff, and the outcome which refers for instance to improvements in clients' health. Generally for human service organizations 'employees are one of the most critical inputs required to deliver on mission and make a difference in the lives of people served' (Selden \& Sowa, 2015, p. 197).

HRM studies (e.g. Aryee, Walumba, Seidu, \& Otaye, 2011; Jiang, Lepak, Hu, \& Baer, 2012; Knies \& Leisink, 2014) provide theoretical explanations and empirical support for the assumption that employees' attitudes and behaviors partially mediate the relationship between HR practices/people management and performance. Jiang et al. (2012) distinguish two theoretical logics that explain the mechanisms linking people management and performance. The first one is a social exchange perspective, which suggests that HRM impacts on performance through employees' attitudes and behaviors. The second one is a resource-based perspective, which focuses on employees' competencies and their impact on employee behavior. Their meta-analysis provides evidence for both mechanisms (see also Combs, Liu, Hall, \& Ketchen, 2006). This perspective is also supported by 
studies in care organizations, such as the one by Piening, Baluch, and Salge (2013) on the relationships between employees' perceptions of HR systems and organizational performance of public hospitals in England.

For human service organizations the importance of the role of line managers in the HRMperformance link has been demonstrated by Alfes, Truss, Soane, Rees, and Gatenby (2013). Their study draws both on the assumptions underlying HPWS-involving that systems of HR practices support employees' abilities, motivation, and opportunity to perform, and thereby their task performance-and on social exchange theory. Alfes et al. show that employees' perceptions of line manager behavior (regarding its effectiveness, equity, and integrity) and of HRM practices are linked with employee engagement which in turn is strongly linked to individual performance. Rowold, Borgmann, and Bormann (2014) report a comparative study of profit and nonprofit organizations regarding the leadership behavior component of line managers' people management impacting on employee attitudes and behavior. They find that different leadership constructs are related to employees' job satisfaction, commitment, and job performance.

The HRM-performance models and the related studies of line managers' people management, employee behaviors, and performance ground the hypothesis that is tested in this article: line managers' people management activities are positively related to thoughtful care in elderly care organizations through employees' behavior.

\section{Research context and research design}

\section{Research context}

This article focuses on elderly care organizations in the Netherlands providing medical and nonmedical care for the elderly. Over the last decade, poor performance in elderly care has frequently attracted media attention, leading to debates in parliament, increased health inspectorate scrutiny, and specific policy interventions. One of the effects of public disapproval was that various stakeholders got together and developed a Quality Framework Responsible Care (2010). This framework was meant to help organizations deal with accountability requirements and the increasing pressure to demonstrate their effectiveness. The quality framework distinguishes between quality of life, quality of care providers, quality of care organizations, and quality of care and safety, supplying tens of indicators for each domain.

However, over recent years critique of this framework has grown. A central element in the critique by elderly care organizations themselves was that the quality framework did not concern what they regard as the essence of care, namely the support for elderly people to continue leading their life as much as they used to. The mounting critique of the framework led the association of elderly care organizations (ActiZ) to develop a vision of the care that elderly care organizations should provide to clients (ActiZ, 2010). The concept 'thoughtful care' was coined to indicate the mission of elderly care organizations to provide care aimed at supporting the autonomy, relatedness, and healthy life of elderly clients. Its continued relevance is illustrated by a recent government policy document which echoes ActiZ' call for thoughtful care under the heading 'Dignity and pride: Loving care for our elderly' (Van Rijn, 2015).

Elderly care in the Netherlands is largely publicly funded and provided by nonprofit organizations. This study is conducted in a large foundation that provides medical and non-medical care for the elderly in 31 residential homes covering a wide region in the southern part of the Netherlands. In total, the organization employs about 4,000 workers. The foundation invited the authors to help them conceptualize thoughtful care and determine the factors that impact on the provision of thoughtful care, including their frontline managers' people management. This section focuses only on the variables relevant for answering this article's research question. 


\section{Exploratory study}

The study reported here consists of a first phase aimed at exploring the concepts of thoughtful care and related employees' behaviors. This exploratory study was conducted in two elderly homes, which differ on several characteristics such as their quality care assessment scores. Several methods were used to collect data. First, several team meetings were attended. Second, 14 working shifts were observed, which involved following the work of individuals and teams of care workers. Third, 30 care workers and supervisors were interviewed. The reason to interview care workers and their supervisors instead of clients themselves is that the mental abilities of the psycho-geriatric clients living in these two homes do not permit them to be interviewed.

The topics for these interviews were distilled from the attended team meetings and the observations. Two open questions guided the interviews. The first question is: what is important from the perspective of a client to make them feel happy? The second question is: what do you need to do in your work to make a client happy? Interviews were recorded and transcribed. Data analysis was done by coding the transcripts using open codes suggested by terms that the interviewees used themselves. Next, labels indicating the variables and/or dimensions of the constructs were extracted by condensing and categorizing the codes.

Three types of specific behaviors needed to provide thoughtful care-paying attention to clients; showing respect for clients; treating each client as an individual person-and descriptions of clients' thoughtful care experiences were derived from the observations and interviews (see Results). We validated these conceptualizations in conversations about the results of the qualitative study with care workers' teams. The rich descriptions provided by the qualitative study were used to generate questionnaire items for a survey of care workers.

\section{Quantitative study}

The second phase of this study is a survey study aimed at validating the constructed scales and testing the hypothesized model. The quantitative data come from 693 employees from 69 teams, providing elderly care in 19 residential homes. Residential homes were free to decide on participation in the research, the foundation had no influence on which residential homes participated. The 19 out of 31 residential homes that participated in the study cover the diversity of types of services provided by the foundation, the urban and rural areas served, and the care inspectorate's assessments of the service quality provided by the residential homes.

The response rate as a percentage of all employees working in the homes that participated in the survey is $67.5 \%$, with 23 men $(3.5 \%)$ and 635 women $(96.5 \%)$. The mean age of the respondents is 43.9 years $(S D=11.8$ years). These averages are quite consistent with Dutch averages for this sector (92\% female, mean age 41 years; ActiZ, 2012). The average job tenure is 10.3 years $(S D=9.3$ years). The majority of respondents are care workers (67.1\%); others work in housekeeping (16.6\%), catering (3.8\%), or other activities (12.6\%). As is usual in elderly care, the majority of employees have taken secondary vocational education (62.4\%); the educational levels of others varied between primary education (2.3\%), general secondary education (19.5\%), higher education (3.1\%), and other/ unknown (12.6\%).

\section{Measures}

The variables outlined below are all measured using five-point Likert scales, with a score of 1 indicating very weak support for the item statement, and a 5 very strong support. The full list of the questionnaire items is included in the appendix.

Following Purcell and Hutchinson (2007), the concept of people management activities is divided into two main components: the application of HR practices and leadership behavior. All respective sub-scales were developed and validated by Knies, Leisink \& Van de Schoot (2017). 
Based on the suggestion by Guest (2007) that two levels of application of HR practices can be distinguished: 'general' practices, which apply to all employees, and tailor-made arrangements with individual employees, the sub-scales measuring line managers' application of HR practices were:

\section{Supportive HR practices}

This variable is based on seven items asking employees to indicate to what extent they felt supported by a range of HR practices being applied (aimed at, for example, training and development, or obtaining a good work-life balance).

\section{Implementation of tailor-made arrangements}

This variable is based on two items asking employees to indicate to what extent tailor-made employment arrangements were negotiated between them and their supervisors.

Leadership behavior is understood as a manager demonstrating supportive behavior and is defined as specific acts that have the intention of helping one's employees. This variable is similarly broken down into two sub-variables:

\section{Support of employees' commitment}

This variable is based on four items asking employees to indicate their support for statements about their supervisor's interest in how they are doing their job, and in their personal functioning.

\section{Support of employees' career development}

This variable is based on four items asking employees to indicate their support for statements about the extent to which their supervisor facilitates their participation in training and their use of career opportunities.

To determine the relationship between the observed variables (questionnaire items) and the latent variables (constructs), we conducted a confirmatory factor analysis (CFA). To assess the model fit, we examined the comparative fit index (CFI), the Tucker-Lewis index (TLI), and the root mean square error of approximation (RMSEA). Acceptable fit is evidenced by a CFI and TLI of .90 or higher, and an RMSEA of .08 or lower (Bentler, 1990). The results of this analysis confirm the existence of the factor structure described above with two modifications. First, the scale measuring 'supportive HR practices' consists of two dimensions: HR practices aimed at supporting employees' commitment (3 items) and HR practices aimed at supporting employees' personal development (2 items). These dimensions parallel the two sub-scales of leadership behavior. Second, based on the fit indices we deleted one of the items of the sub-scale 'support of employees' career development', resulting in a 3-item scale. The standardized coefficients all had values between .672 and .943 . Additional information on the results of the CFA is provided in the appendix.

To verify whether these sub-scales are indeed dimensions of the underlying construct people management, we conducted third-order CFA. First, we loaded the two sub-dimensions of 'supportive HR practices' on the second-order construct. This second-order model was significant. Second, we loaded all four sub-scales (supportive HR practices, implementation of tailor-made arrangements, support of employees' commitment, and support of employees' career development) on the thirdorder construct. The results of these tests confirm the proposed structure. Factor loadings of the four sub-dimensions on the third-order construct vary between .728 and .911 . Fit indices for this model are acceptable (CFI $=.987$; TLI $=.966$; RMSEA $=.110)$. The Cronbach's alphas for reliability are good for all sub-scales as well as for the overall construct (>.70). Because the mediating variables measuring employees' behaviors and the dependent variable thoughtful care are developed for this study, these variables are discussed in the results section. 


\section{Developing a compact measure}

One of the aims of this paper is to deliver a compact measure of mission achievement. Here, we elaborate on our understanding of a compact measure and deduce several features which characterize it. In the next section we apply these criteria to develop a measure of mission achievement in elderly care. DeVellis (2003, p. 97) states that generally shorter scales are preferred over longer ones because these place less of a burden on respondents. Schaufeli, Bakker, and Salanova (2006, p. 702-703) add that long questionnaires increase the likelihood of attrition. According to DeVellis, there exists an inherent trade-off between reliability and brevity. The challenge is to find the right balance between the two. That is, developing a measure that is short ánd reliable. Looking at examples of previously developed and validated scales which claim to be 'short', 'compact', or 'abridged' (e.g. public service motivation: Coursey \& Pandey, 2007; work engagement: Schaufeli et al., 2006; leader-member exchange: Schriesheim, Neider, Scandura, \& Tepper, 1992), we note that the length of the scale varies between 6 and 10 items, depending on the complexity and nature of the concept. This gives us a good indication of the usual length of a compact measure.

\section{Measurement quality}

The data for all the items were collected from individual respondents and are thus potentially subject to common method bias (CMB) (Podsakoff, MacKenzie, Lee, \& Podsakoff, 2003). Although a recent study shows that in contrast to conventional wisdom, common method effects do not appear to be so large as to pose a serious threat to organizational research' (Lance, Dawson, Birkelbach, \& Hoffman, 2010, p. 450), we have addressed this potential problem in various ways.

We enhanced construct validity by formulating questionnaire items about people management such that they refer to employees' perceptions of specific concrete behaviors of line managers. The items measuring employees' behavior all refer to specific concrete actions undertaken by individual employees, such as 'I listen...', 'I inform...' and 'I respect...'. To measure our dependent variable 'thoughtful care' we requested respondents to take a client's perspective, by formulating items starting with 'my clients...' (see also Results). By conceptually separating employees' behavior and the outcomes of these behaviors for clients, we tried to limit conceptual overlap between the variables. Moreover, in the survey design, we spread the items relating to different variables among various sections of the questionnaire. Further, we conducted two sets of CFAs to check for $\mathrm{CMB}$ in the data, comparing the hypothesized structure (CFI = .989; $\mathrm{TLI}=.987$; RMSEA $=.037)$ with a one-factor model $(\mathrm{CFI}=.737$; TLI $=.717$; $\mathrm{RMSEA}=.177$ ). The analyses provide evidence against there being a bias stemming from common method variance (Podsakoff et al., 2003).

One obvious risk of self-reporting measures is that respondents tend to inflate their ratings, and so the scores should be regarded with some caution. However, inflated self-ratings should not affect the relationships, and it is these in which we are most interested.

\section{Data analysis}

In the following section, we first describe the development and validation of the mediating and dependent variables based on the qualitative and quantitative parts of our study. Next, we provide the descriptive statistics and correlations for the variables used. Then, we present the results of the model tests, for which we used structural equation modeling (SEM) techniques. Because our respondents are nested in supervisor groups, the non-independence of observations was taken into account by using the 'TYPE = COMPLEX' analysis command in MPlus. In the model tests we controlled for age, tenure, gender, and educational level, which are frequently used as control variables in HRM research (Boselie, Dietz, \& Boon, 2005). 


\section{Results}

\section{Developing measures for thoughtful care and related employees' behaviors}

The mediating variable employees' behaviors required to provide thoughtful care consisted, according to the care workers interviewed, of three dimensions: paying attention to clients, acting respectfully, and treating each client as an individual person.

\section{Attention}

Employees providing thoughtful care pay attention to clients. They regularly talk to clients, listen to their problems, take the time to do some extra and if necessary, try to find a solution for clients' problems. From the exploratory study four items were developed to measure this dimension.

Interviewed care workers were unanimous that 'attention is always important for every client'. One care worker observes: 'For instance, when a client rings the bell for assistance, it is important that one of us reacts immediately so that the client feels he is listened to'. Another care worker says: 'One should take extra time for a client occasionally, for instance for trimming and painting her nails or putting on make-up. Another client may feel happy by making a walk together'.

\section{Respect}

Employees who show respect for their clients do not impose their own norms and values but respect their clients' norms and values and respect their clients' need for privacy. Moreover, they inform clients about their actions. For example, why clients have to wait or why they receive new medication. Another indicator of respect is living up to the promises made to clients. Five items were generated to measure this dimension.

Care workers agree that it is important to respect the personal values and lifestyle of each client. An example given by one care worker illustrates this. 'The room of one of our clients is spilling over with knick-knacks. I have to remind myself that she likes it this way and that I have to respect this. These are not my values but hers. I think that we always have to respect these'. Respect involves according to another care worker 'that you call them when you will be late. And when you tell them that you will be 10 minutes late, you shouldn't actually be there half an hour late, that is not honest'.

\section{Individual approach}

Taking an individual or personal approach-as opposed to a standardized or collective one-is another important type of behavior requisite for thoughtful care. This includes meeting the needs of individual clients, attending to their personal habits and routines, and involving them in decision making. Four items were taken from the exploratory study to measure this dimension.

One care worker gives the following answer to the question what makes a client smile: 'One should really do what clients ask and like. That is very different for clients. One client likes a joke, another a gentle stroke. You adapt yourself to each client'. Another care worker stresses the importance of care workers giving clients a choice. 'For instance, what sandwich filling they want, at what time they want to wake up or go to bed'.

\section{Thoughtful care}

The dependent variable in our study is thoughtful care. According to the care workers clients are happy in terms of thoughtful care when they are satisfied with the care they receive, feel that they are listened to, and treated respectfully, have a say in the care provided and can continue living their life as they were used to. Seven items were generated to measure this variable.

Interviewed care workers explain that it is sometimes difficult for them to know whether and when psychogeriatric patients are satisfied. But they know that preventing restlessness is important: 'In the morning when I help clients get up I am busy with one client and then another one wakes up. 
This latter lady will have to wait. If it is only a few minutes that is not a problem, but if it takes more than 10 minutes she starts to cry and gets restless'. Generally, clients' satisfaction is regarded as the most important indicator of thoughtful care. 'Clients are happy when everything went to their satisfaction'. 'When you leave a client's room and they say "thank you" or smile... you know they are satisfied and happy'.

The items measuring thoughtful care relate to the three dimensions of public service performance distinguished by Boyne (2002) that we designated as the primary service quality interests of the service user, namely service outputs and outcomes, and responsiveness in terms of satisfaction by direct service users. These items reflect the interests of the stakeholder client. However, they are measured as employees' perceptions of clients' experience of thoughtful care. The use of employees' perceptions of service quality is not uncommon in studies of human service organizations (e.g. Agbényiga, 2011; Cronley \& Kim, 2014). Also, employees' perceptions appear to be correlated with client perceptions (Cronley \& Kim, 2014, p. 85). The specific reason in this survey for asking employees' perceptions of the thoughtful care experience of clients is that it would have been very difficult to ask clients themselves as the majority are psychogeriatric clients.

\section{Construct validation}

Construct validation for these new scales was carried out using Mplus (Muthén \& Muthén, 2012). First, we examined the dimensionality of employees' care behaviors and thoughtful care scales by performing an exploratory factor analysis (EFA). We used principal component factoring and direct oblimin rotation, because this allows for the factors to be correlated. We included all 20 items generated to measure these constructs in the analysis. We examined the number of factors extracted with eigenvalues greater than or equal to one. This indicated four factors, which together explained $57.3 \%$ of the total variance in the measure. The factor structure was as we expected. All items had factor loadings of .40 or higher.

Second, we performed CFAs. For the items measuring employees' care behavior, we tested a firstorder model based on the results of the EFA, in which four items loaded on the dimension 'attention', five items on the dimension 'respect' and four items on the dimension 'individual approach'. The initial CFA showed unacceptable fit indices. Therefore, we excluded one item from each dimension, based on factor loadings and item errors. As a result, the fit increased substantially. Fit indices are as follows: CFI $=.987$; TLI $=.982$; RMSEA $=.061$. All items loaded significantly on the latent variables $(p<.001)$. Factor loadings ranged from .650 to .890 . Because we conceptualized that these three variables (attention, respect, and individual approach) are dimensions of the underlying construct employees' care behavior, we conducted a second-order CFA. The results of this test confirm the proposed structure. Factor loadings of the three sub-dimensions on the second-order construct vary between .811 and .979 . Figure 1 displays the final factor structure of the items measuring employees' care behavior. In summary, the results of the CFA support a three-dimensional scale comprised of 10 items.

We also conducted a CFA for the items measuring thoughtful care. Initially, model results indicated a poor fit. Based on factor loadings and item errors we deleted two items. The resulting five items show good fit indices $($ CFI $=.995$; TLI $=.990$; RMSEA $=.095)$. All items loaded significantly on the latent variable $(p<.001)$. Factor loadings ranged from .766 to .886 . Figure 2 displays the factor structure of the items measuring thoughtful care. Thus, the results of the CFA support a factor comprised of five items.

Third, we assessed the reliability of the scales by examining the coefficients Cronbach's alpha's. The three sub-scales of employees' care behavior all showed sufficient reliability. Cronbach's alphas were .721 for 'attention', .713 for 'respect', and .745 for 'individual approach'. The reliability estimate for the overall scale was .847 , which is considered very good. The coefficient alpha estimate of 


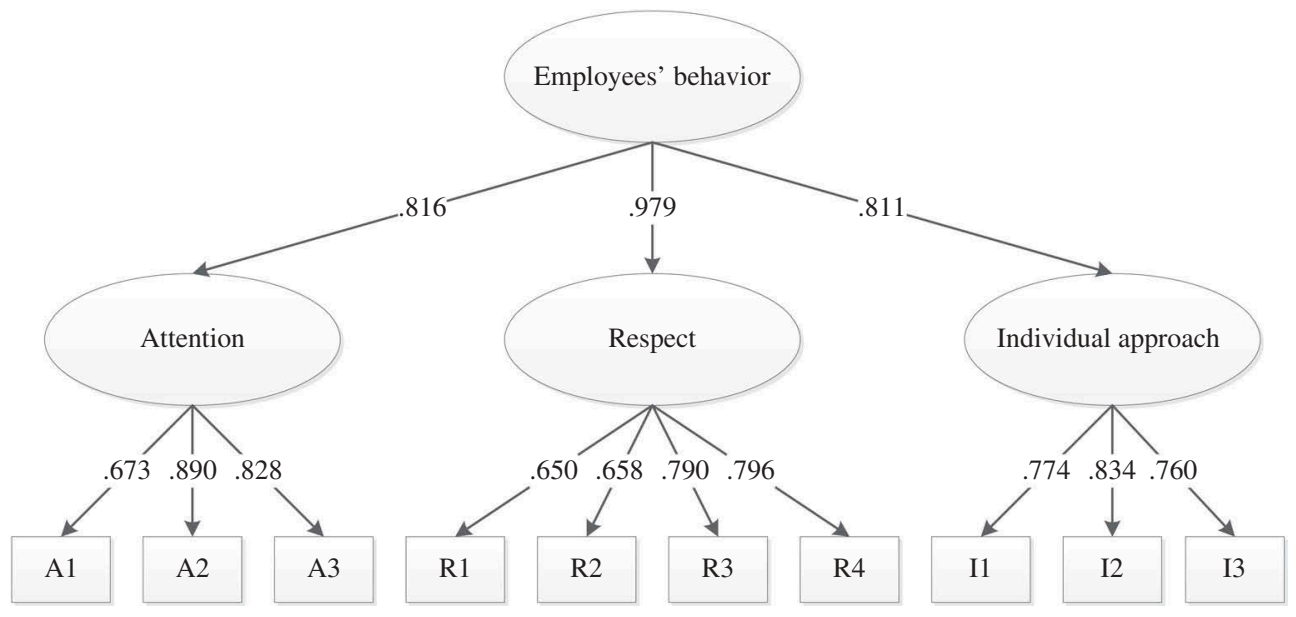

Figure 1. Factor structure employees' behavior.

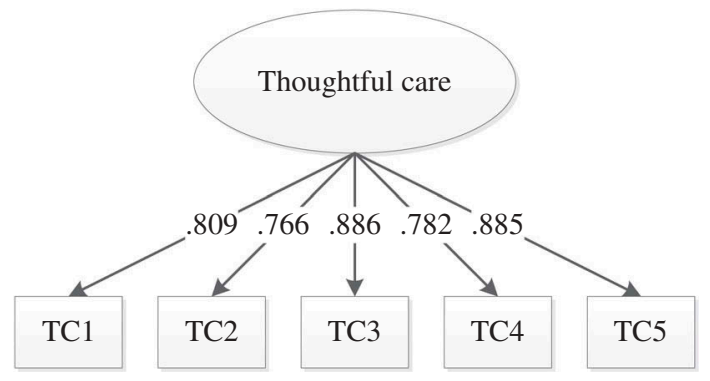

Figure 2. Factor structure thoughtful care.

reliability was also very good for the variable 'thoughtful care' (.859). Thus, the results of our analyses indicate that the employees' care behavior and thoughtful care scales are reliable measures.

A potential bias is introduced by the fact that we measure thoughtful care from a client perspective by surveying employees. We have addressed the potential problem of bias in various ways. We explicitly requested employees to take a client perspective, by formulating items starting with 'my clients.... Further, we have data from the Consumer Quality Index (CQ-index), which provides information about the quality of care from the perspective of care users (or their relatives) at the level of homes. The index is an additive measure of various aspects of quality of care. We computed the mean score of thoughtful care at the level of a residential home from the scores of all employees serving one residential home. The correlation between the score from the CQ-index and our measure of thoughtful care is significant $(r=.516, p=.003)$. This indicates that the scores obtained by surveying employees show similar patterns to client responses. This supports our claim that effects of this source of potential bias are limited.

\section{Descriptive statistics and correlations}

Table 1 presents the means, standard deviations, and correlations for the variables used in our quantitative study.

The results in Table 1 show that employees were moderately positive about the people management activities undertaken by their supervisors with all the average scores above the theoretical scale midpoint 
Table 1. Descriptive statistics and correlations.

\begin{tabular}{lccccc}
\hline & Mean & SD & 1 & 2 & 3 \\
\hline 1. People management activities & 3.60 & 0.56 & 1.00 & & \\
2. Employees' behavior & 4.34 & 0.42 & $.439^{* * *}$ & 1.00 & $.771^{* * *}$ \\
3. Thoughtful care & 4.11 & 0.49 & $.382^{* * *}$ & .014 & 1.00 \\
4. Gender (1 = female) & n.a. & n.a. & $-.075^{*}$ & -.045 \\
5. Age & 43.9 & 11.8 & -.037 & .008 & .082 \\
6. Tenure & 10.3 & 9.3 & -.063 & -.078 & .009 \\
7. Educational level & n.a. & n.a. & .034 & .015 & .004 \\
\hline
\end{tabular}

** $p<.001 ;{ }^{*} p<.05 ;$ n.a. not applicable

(3.60, $S D=0.56)$. Employees reported high levels of thoughtful care-related behavior $(4.34, S D=0.42)$, indicating that they pay attention to the needs of clients, act respectfully, and take an individual approach. The score on the outcome variable 'thoughtful care' indicates that respondents report high levels (4.11, $S D=0.49$ ).

The correlation analysis displayed in Table 1 shows that people management is significantly related to both employee behavior and thoughtful care. The correlation coefficients are $.439(p<.001)$ and .382 $(p<.001)$ respectively. The results also show that employee behavior and thoughtful care are significantly related $(r=.771, p<.001)$. With one exception, none of the control variables was related significantly to people management activities, employee behavior, or thoughtful care. Only gender was significantly related to people management activities $(r=.075, p<.05)$ : women reported slightly lower levels of people management support from their supervisors than men.

\section{Model test}

In order to test our model, we first analyzed whether a mediated model as developed in the theoretical framework produced the best model fit compared to a direct model. This analysis is based on the minimization of the Akaike Information Criterion (AIC) and the Bayesian Information Criterion (BIC). These fit indexes can be used to compare models, where lower scores indicate superior models (Schreiber, Nora, Stage, Barlow, \& King, 2006). In the first model, we assumed that people management had a direct effect on thoughtful care. The AIC score was 31,954 and the BIC score was 32,410. In the second model, we tested the mediated effect of people management activities on thoughtful care through employee behavior ( $\mathrm{AIC}=31,822$; $\mathrm{BIC}=32,279$ ). These results show that the mediated model had the lowest AIC and BIC scores, meaning that this model is the preferred one. Therefore, results from the mediated model are presented.

Table 2 presents the results of the model test. Fit indices show a good model fit (CFI $=.983$; TLI $=.981$; RMSEA $=.033)$. People management is significantly related to employee behavior $(\beta=.513, p<.001)$. In turn, employee behavior is significantly related to thoughtful care $(\beta=.802, p<.001)$. This implies that the indirect path from people management through employee behavior on thoughtful care is also significant $(\beta=.411, p<.001)$, meaning that we found support for our hypothesis. None of the control variables included in our model test (gender, age, tenure, educational level) was significant.

Table 2. Mediated SEM model.

\begin{tabular}{|c|c|c|c|c|}
\hline & $\beta$ & B & S.E. & $p$ \\
\hline People management $\rightarrow$ Employees' behavior & .513 & 0.496 & .058 & .000 \\
\hline Employees' behavior $\rightarrow$ Thoughtful care & .802 & 1.134 & .102 & .000 \\
\hline People management $\rightarrow$ Employees' behavior $\rightarrow$ thoughtful care & .411 & 0.563 & .061 & .000 \\
\hline$R^{2}$ Employees' behavior & .287 & & & \\
\hline$R^{2}$ Thoughtful care & .645 & & & \\
\hline
\end{tabular}

\footnotetext{
${ }^{a}$ None of the control variables is significant

${ }^{\mathrm{b}}$ Fit indices: $\mathrm{CFI}=.983 ; \mathrm{TLI}=.981 ; \mathrm{RMSEA}=.033$
} 
Overall, the levels of explained variance are quite high. The explained variance is $28.7 \%$ in the case of employee behavior. This can be attributed to the effect of people management. The level of explained variance for thoughtful care is $64.5 \%$. This can be attributed to the mediated effect of people management through employee behavior.

\section{Conclusion and discussion}

This article set out to answer the question to what extent frontline managers' people management activities contribute to mission achievement through frontline workers' behaviors. Drawing on the case of elderly care, the results of our study provide support for our hypothesis that line managers' people management activities are positively related to mission achievement (i.e. thoughtful care performance in elderly care) mediated by care workers' behaviors. Our results also show that thoughtful care is a valid measure of the mission defined by elderly care organizations in the face of the current challenges of long-term care for older people. Moreover, the results reveal that care workers' behavior that contributes to thoughtful care consists of the following dimensions: paying attention, showing respect, and treating each client as an individual person.

\section{This study's contributions}

These results are of interest to the study of mission achievement of human service organizations and human service management in various respects. First, a valid measure of 'thoughtful care' is relevant for a number of reasons. The construct relates to the mission of elderly care organizations and is based on what organizational stakeholders regard as the essence of the care they provide with the client as the focal stakeholder. The mission achievement is assessed by a compact measure of five items that relates to three dimensions of public service performance conceptualized by Boyne (2002): service outputs and outcomes, and responsiveness in terms of satisfaction by direct service users. This compact measure helps to see the forest from the trees represented by the tens and hundreds of performance indicators suggested by performance studies. We regard the measure of thoughtful care as a sector-specific complement to generic measures of public service performance (Andrews et al., 2006). The importance of a context-specific construct is related, as we argued in the theoretical framework, to the fact that effectiveness means different things for different nonprofit and public organizations because of the specificity of their missions (Rainey \& Steinbauer, 1999; Sowa et al., 2004). In this study, we also conceptualized the thoughtful carerelated behavior of care workers, which pertains to the process of service provision while thoughtful care itself concerns the service product. Our context-specific measures of thoughtful care and related behavior of care workers increases the validity of research, because respondents better understand specific than generic survey questions (Meier \& O'Toole, 2013), especially as we have distilled these questions from conversations with care workers. In this article, we developed a scale to measure mission achievement in elderly care. We hope that our endeavor will inspire others to do the same for mission achievement in other public and nonprofit sectors and that this piece provides directions how to tackle this task specifically with regard to contextualizing the scale using qualitative data as input.

Second, the results of our study are of interest because they demonstrate that people management matters and that line managers contribute to mission achievement by supporting employees' behavior. The notion that employee attributes are positively related to customer service quality and ultimately organizational performance is the basis of Heskett et al.'s (1994) service-profit chain model and is empirically corroborated in profit service industry studies (e.g. Yee, Yeung, \& Cheng, 2010). Our study provides empirical support for the notion that employees' behaviors are vital for service quality and mission achievement in nonprofit human service organizations (see also Sowa et al., 2004). In addition, this study shows that frontline managers can make a considerable 
contribution to mission achievement by supporting the employees they supervise by their people management activities, that is their implementation of HR practices and their leadership behavior. This is a contribution to the public management literature which has questioned the efficacy of managers because of the constraints on managerial autonomy and the prevalence of detailed regulations in the area of personnel policies (Brewer \& Walker, 2012; Feeney \& Rainey, 2010). Our study shows that, at least in elderly care in the Netherlands, line managers can contribute to thoughtful care performance through their people management. As such our study contributes to systemizing knowledge on the management-performance relationship and ultimately to theory development as called for by Abner, Kim, and Perry (2017).

\section{Limitations}

We note that our study has some limitations. First, in our study we decided to concentrate on a context-specific measure of mission achievement because this adds to the current body of literature which generally focuses on the generic dimensions of performance. In follow-up studies, it would be interesting to include both types of measures (generic and context-specific) to examine to what extent these are related.

Second, in our study we used a subjective measure of thoughtful care. Because thoughtful care concerns the interior experiences and perceptions of older clients we believe that a subjective measure is apt (Andersen et al., 2016, p. 5) but also that the actor perspective in the survey should ideally align with this focal stakeholder. Although we explicitly requested employees to take a client perspective, and although our analyses showed that our measure of thoughtful care is significantly related to the score on the CQ-index, we recommend that in future studies, clients (or their relatives) are used as respondents expressing their perceptions of thoughtful care.

Third, the results of our study show that our measures of thoughtful care and related employees' behavior are highly correlated. This could point to conceptual overlap between our variables. In our operationalization of thoughtful care-related behavior we referred to specific concrete actions undertaken by individual employees, whereas in our measure of thoughtful care we captured (employees' perceptions of) clients' experience with the provided care. In follow-up studies, this potential overlap might be further reduced by focusing more specifically on client perceptions of the outcomes of care leaving out the process of care provision. Despite these limitations, our results provide substantial evidence for answers to the core issues addressed in the introduction.

\section{Implications}

We provided a compact context-specific measure of mission achievement in elderly care. Moreover, we showed that people management activities as perceived by employees have a significant impact on employees' behavior, which is the linking mechanism in the relationship between people management and mission achievement.

These findings also have important implications for practice. Our measures of mission achievement in elderly care and the related employee behaviors can be a used as a diagnostic tool in elderly care organizations. The measure can help to gain insight into the way clients experience the care that is provided to them, capturing the essence of service provision in this particular sector. This provides practitioners with a tool to benchmark organizational units' thoughtful care performance and locate units that deserve specific attention. Moreover, this scale can be administered to facilitate discussions between team members about the mission achievement and potential interventions aimed at improving the provision of thoughtful care. One such intervention is continuous investment in people management. Our study shows that people management matters, which 
implies that human service organizations can improve mission achievement by designated people management activities.

\section{Acknowledgment}

We want to thank Mandy Onwezen and Kimberley van Bijsteren for their assistance in the exploratory study.

\section{Funding}

This work was supported by the Nederlandse Organisatie voor Wetenschappelijk Onderzoek [451-15-002].

\section{References}

Abner, G., Kim, S., \& Perry, J. (2017). Building evidence for public human resource management: Using middle range theory to link theory and data. Review of Public Personnel Administration, 37(2): 139-159. 0734371 $\times 17697248$.

ActiZ. (2010). Naar autonomie, verbondenheid en een gezond leven: Een nieuwe ambitie voor de langdurige zorg. Utrecht, The Netherlands: Author.

ActiZ. (2012). De verpleeg- en verzorgingshuiszorg en thuiszorg in kaart: Feiten, financiering, kosten en opbrengsten. Retrieved from www.actiz.nl.

Agbényiga, D. (2011). Organizational culture-performance link in the human services setting. Administration in Social Work, 35(5), 532-547.

Alfes, K., Truss, C., Soane, E., Rees, C., \& Gatenby, M. (2013). The relationship between line manager behaviour, perceived HR practices, and individual performance: Examining the mediating role of engagement. Human Resource Management, 52(6), 839-859.

Andersen, L., Boesen, A., \& Pedersen, L. (2016). Performance in public organizations: Clarifying the conceptual space. Public Administration Review. doi:10.1111/puar.12578

Andrews, R., \& Boyne, G. (2010). Capacity, leadership and organizational performance: Testing the black box model of public management. Public Administration Review, 70(3), 443-454.

Andrews, R., Boyne, G., \& Walker, R. (2006). Subjective and objective measures of organizational performance: An empirical investigation. In: G. Boyne, K. Meier, L. O’Toole, \& R. Walker (eds.), Public service performance: Perspectives on measurement and management (pp. 14-34). Cambridge, UK: Cambridge University Press.

Ang, S., Bartram, T., McNeil, N., Leggat, S., \& Stanton, P. (2013). The effects of high-performance work systems on hospital employees' work attitudes and intention to leave: A multi-level and occupational group analysis. International Journal of Human Resource Management, 24(16), 3086-3114.

Aryee, S., Walumba, F., Seidu, E., \& Otaye, L. (2011). Impact of high-performance work systems on individual- and branchlevel performance: Test of a multilevel model of intermediate linkages. Journal of Applied Psychology, 97(2), $287-300$.

Barney, J. (1991). Firm resources and sustained competitive advantage. Journal of Management, 17(1), 99-120.

Bentler, P. M. (1990). Comparative fit indexes in structural models. Psychological Bulletin, 107(2), $238-246$.

Boon, C., Den Hartog, D. N., Boselie, P., \& Paauwe, J. (2011). The relationship between perceptions of HR practices and employee outcomes: Examining the role of person-organisation and person-job fit. The International Journal of Human Resource Management, 22(1), 138-162.

Boselie, P., Dietz, G., \& Boon, C. (2005). Commonalities and contradictions in HRM and performance research. Human Resource Management Journal, 15(3), 67-94.

Boselie, P., \& Veld, M. (2012). Human resource management and commitment in Dutch child day care. Administration in Social Work, 36(2), 189-211.

Boyne, G. (2002). Concepts and indicators of local authority performance: An evaluation of the statutory frameworks in England and Wales. Public Money \& Management, 22(2), 17-24.

Brewer, G., \& Walker, R. (2012). Personnel constraints in public organizations: The impact of reward and punishment on organizational performance. Public Administration Review, 73(1), 121-131.

Brewster, C., Brookes, M., \& Gollan, P. (2015). The institutional antecedents of the assignment of HRM responsibilities to line managers. Human Resource Management, 54(4), 577-597.

Carnochan, S., Samples, M., Myers, M., \& Austin, M. (2014). Performance measurement challenges in non-profit human service organizations. Nonprofit and Voluntary Sector Quarterly, 43(6), 1014-1032.

Combs, J., Liu, Y., Hall, A., \& Ketchen, D. (2006). How much do high-performance work practices matter? A metaanalysis of their effects on organizational performance. Personnel Psychology, 59(3), 501-528.

Cooke, F., \& Bartram, T. (2015). Guest editors' introduction: Human Resource Management in health care and elderly care: Current challenges and toward a research agenda. Human Resource Management, 54(5), 711-735. 
Coursey, D. H., \& Pandey, S. K. (2007). Public service motivation measurement testing an abridged version of Perry's proposed scale. Administration \& Society, 39(5), 547-568.

Cronley, C., \& Kim, Y. (2014). The path to service quality: The mediating role of organizational commitment on the effects of strategic planning and technology access within the Salvation Army. Human Service Organizations: Management, Leadership \& Governance, 38(1), 74-88.

Deusdad, B., Pace, C., \& Anttonen, A. (2016). Facing the challenges in the development of long-term care for older people in Europe in the context of an economic crisis. Journal of Social Service Research, 42(2), 144-150.

DeVellis, R. F. (2003). Scale development: Theory and applications. Thousand Oaks, California, US: Sage.

Donabedian, A. (1980). Exploration in quality assessment and monitoring. Ann Arbor, Michigan, US: Health Administration Press.

Eisenberger, R., Huntington, R., Hutchinson, S., \& Sowa, D. (1986). Perceived organisational support. Journal of Applied Psychology, 71(3), 500-507.

Feeney, M., \& Rainey, H. (2010). Personnel flexibility and red tape in public and non-profit organizations: Distinctions due to institutional and political accountability. Journal of Public Administration Research and Theory, 20(4), 801826.

Greenhaus, J., Parasuraman, A., \& Wormley, W. (1990). Effects of race on organizational experiences, job performance evaluations, and career outcomes. Academy of Management Journal, 33(1), 64-86.

Guest, D. E. (2007). HRM: Towards a new psychological contract?. In: P. Boxall, J. Purcell, \& P. Wright (eds.), The Oxford handbook of human resource management (pp. 128-146). Oxford, UK: Oxford University Press.

Guest, D. E. (2011). Human resource management and performance: Still searching for some answers. Human Resource Management Journal, 21, 3-13.

Hasenfeld, Y. (2015). What exactly is human services management? Human Service Organizations: Management, Leadership \& Governance, 39(1), 1-5.

Heskett, J., Jones, T., Loveman, G., Sasser, W., \& Schlesinger, L. (1994). Putting the service-profit chain to work. Harvard Business Review, 72(2), 164-174.

Huselid, M. (1995). The impact of human resource management practices on turnover, productivity, and corporate financial performance. Academy of Management Journal, 38(3), 635-672.

Jiang, K., Lepak, D. P., Hu, J., \& Baer, J. C. (2012). How does human resource management influence organizational outcomes? A meta-analytic investigation of mediating mechanisms. Academy of Management Journal, 55(6), $1264-1294$.

Knies, E., \& Leisink, P. (2014). Linking people management and extra-role behaviour: Results of a longitudinal study. Human Resource Management Journal, 24(1), 57-76.

Knies, E., Leisink, P. L. M. \& Van de Schoot, R. (2017), 'People management: developing and testing a measurement scale', International Journal of Human Resource Management, 1-33.

Lance, C. E., Dawson, B., Birkelbach, D., \& Hoffman, B. J. (2010). Method effects, measurement error, and substantive conclusions. Organizational Research Methods, 13(3), 435-455.

Larsen, H. H., \& Brewster, C. (2003). Line management responsibility for HRM: What is happening in Europe? Employee Relations, 25(3), 228-244.

Lynn, L. E., Heinrich, C. J., \& Hill, C. J. (2000). Studying governance and public management: Challenges and prospects. Journal of Public Administration Research and Theory, 10(2), 233-262.

Meier, K., \& O’Toole, L. (2013). I think (I am doing well), therefore I am: Assessing the validity of administrators' selfassessments of performance. International Public Management Journal, 16(1), 1-27.

Meier, K., O’Toole, L., Boyne, G., \& Walker, R. (2007). Strategic management and the performance of public organisations: Testing venerable ideas against recent theories. Journal of Public Administration Research and Theory, 17(2), 357-377.

Moynihan, D., \& Pandey, S. (2005). Testing how management matters in an era of government by performance management. Journal of Public Administration Research and Theory, 15(3), 421-439.

Muthén, B., \& Muthén, L. (2012). User guide MPlus. Los Angeles, CA: Muthén \& Muthén.

Nishii, L. H., Lepak, D. P., \& Schneider, B. (2008). Employee attributions of the "why" of HR practices: Their effects on employee attitudes and behaviors, and customer satisfaction. Personnel Psychology, 61, 503-545.

Oldham, G., \& Cummings, A. (1996). Employee creativity: Personal and contextual factors at work. Academy of Management Journal, 39(3), 607-634.

Paauwe, J. (2009). HRM and performance: Achievements, methodological issues and prospects. Journal of Management Studies, 46(1), 129-142.

Piening, E. P., Baluch, A. M., \& Salge, T. O. (2013). The relationship between employees' perceptions of human resource systems and organizational performance: Examining mediating mechanisms and temporal dynamics. Journal of Applied Psychology, 98(6), 926-947.

Podsakoff, P. M., MacKenzie, S. B., Lee, J., \& Podsakoff, N. P. (2003). Common method variance in behavioral research: A critical review of the literature and recommended remedies. Journal of Applied Psychology, 88, 879-903.

Purcell, J., \& Hutchinson, S. (2007). Front-line managers as agents in the HRM-performance causal chain: Theory, analysis and evidence. Human Resource Management Journal, 17(1), 3-20. 
Purcell, J., \& Kinnie, N. (2007). HRM and business performance. In: P. Boxall, J. Purcell, \& P. Wright (eds.), The Oxford handbook of human resource management (pp. 533-551). Oxford, UK: Oxford University Press.

Quality Framework Responsible Care (2010). Den Haag: Stuurgroep Kwaliteitskader Verantwoorde Zorg. Retrieved from www.zichtbarezorg.nl.

Rainey, H., \& Steinbauer, P. (1999). Galloping elephants: Developing elements of a theory of effective government organizations. Journal of Public Administration Research and Theory, 9(1), 1-32.

Rhoades, L., \& Eisenberger, R. (2002). Perceived organizational support: A review of the literature. Journal of Applied Psychology, 87(4), 698-714.

Riccucci, N. (2005). How management matters: Street-level bureaucrats and welfare reform. Washington DC, US: Georgetown University Press.

Richard, P., Devinney, T., Yip, G., \& Johnson, G. (2009). Measuring organizational performance: Towards methodological best practice. Journal of Management, 35(3), 718-804.

Rowold, J., Borgmann, L., \& Bormann, K. (2014). Which leadership constructs are important for predicting job satisfaction, affective commitment, and perceived job performance in profit versus non-profit organizations? Nonprofit Management \& Leadership, 25(2), 147-164.

Schaufeli, W. B., Bakker, A. B., \& Salanova, M. (2006). The measurement of work engagement with a short questionnaire: A cross-national study. Educational and Psychological Measurement, 66(4), 701-716.

Schreiber, J. B., Nora, A., Stage, F. K., Barlow, E. A., \& King, J. (2006). Reporting structural equation modeling and confirmatory factor analysis results: A review. The Journal of Educational Research, 99(6), 323-338.

Schriesheim, C. A., Neider, L. L., Scandura, T. A., \& Tepper, B. J. (1992). Development and preliminary validation of a new scale (LMX-6) to measure leader-member exchange in organizations. Educational and Psychological Measurement, 52(1), 135-147.

Selden, S., \& Sowa, J. (2015). Voluntary turnover in non-profit human service organizations: The impact of high performance work practices. Human Service Organizations: Management, Leadership \& Governance, 39(3), $182-207$.

Sowa, J., Selden, S., \& Sandfort, J. (2004). No longer unmeasurable? A multidimensional integrated model of nonprofit organizational effectiveness. Nonprofit and Voluntary Sector Quarterly, 33(4), 711-728.

Van Rijn, M. (2015). Waardigheid en trots. Liefdevolle zorg voor onze ouderen. Den Haag, The Netherlands: Ministerie van Volksgezondheid, Welzijn en Sport.

Wright, P., \& Nishii, L. (2013). Strategic HRM and organizational behaviour: Integrating multiple levels of analysis. In: J. Paauwe, D. E. Guest, \& P. M. Wright (Eds.), HRM \& performance: Achievements \& challenges (pp. 97-110). Chichester, West Sussex: Wiley.

Yee, R., Yeung, A., \& Cheng, T. (2010). An empirical study of employee loyalty, service quality and firm performance in the service industry. International Journal of Production Economics, 124(1), 109-120. 


\section{Appendix}

Supportive HR practices: employees' commitment

I experience the following HR practices as being implemented to support me:

- changes in job design

- vitality

- work-life balance

Supportive HR practices: employees' career development

I experience the following HR practices as being implemented to support me:

- training and development

- mobility

Implementation of tailor-made arrangements

My supervisor tailors employment conditions to my personal situation

My supervisor tailors employment conditions to my individual needs so I can do a better job $\quad .914$

\section{Support of employees' commitment}

My supervisor shows an interest in how I do my job $\quad .943$

$\begin{array}{lr}\text { My supervisor shows an interest in my personal functioning } & .928\end{array}$

If my supervisor appreciates the job done by me, he/she does not let this pass unnoticed $\quad .908$

$\begin{array}{ll}\text { My supervisor asks me if I can manage my job } & .877\end{array}$

Support of employees' career development
My supervisor informs me about opportunities for training and development

$\begin{array}{lr}\text { My supervisor offers me opportunities to participate in training } & .906\end{array}$

$\begin{array}{lr}\text { My supervisor supports me in utilizing opportunities for vertical mobility } & .839\end{array}$

\section{Attention}

A1 During my work I talk regularly with my clients

A2 I listen to the problems of my clients

A3 If problems occur I will look for a solution together with the client $\quad .828$

\section{Respect}

R1 I do not argue with clients about their norms and values (e.g. as regards expressions of religion or the design of the .650 room)

R2 I inform my clients about my actions (e.g. as regards new medication or delays in service)

$\begin{array}{ll}\text { R3 I always live up to my promises } & .790\end{array}$

R4 I respect my clients' need for privacy (e.g. as regards toilet use) Individual approach

I1 I meet the personal needs of my clients

12 I keep up the personal habits and routines of my clients

I3 I involve my clients in decision making $\quad .760$ Thoughtful care

$\begin{array}{ll}\text { TC1 My clients are satisfied with the care they receive from me } & .809\end{array}$

TC2 My clients can continue their lifestyle as I take care of them

TC3 My clients feel that I listen to their needs and wishes 886

TC4 My clients have a say in the care they receive from me $\quad .782$

TC5 My clients feel that I treat them with respect $\quad .885$ 